\title{
ANTIBACTERIAL AND MECHANICAL ASSAYS OF RESIN MODIFIED GLASS IONOMER CONTAINING PROPOLIS EXTRACT
}

\author{
Talat Mohamed Beltagy* and Marwa Ezzat Abd-Elmonsef ${ }^{* *}$
}

\begin{abstract}
The antibacterial efficacy of restorative materials had an important role in preventing the recurrent caries. The objective of this study was to evaluate in-vitro the antibacterial and mechanical assays of Vitremer containing ethanolic extract of propolis (EEP). Materials and methods: I-Antibacterial Assay: The standard strain of Streptococcus mutans and Lactobacillus acidophilus were used for determination of minimum inhibitory concentration (MIC) of EEP/Vitremer. IIMechanical Assay: A-Shear bond strength (SBS): sixty half-crowns of non-carious extracted $2^{\text {nd }}$ primary molars were placed at standard moulds containing Teflon disc that had $4 \mathrm{~mm} \times 3 \mathrm{~mm}$ central hole and divided into 4 groups $(\mathrm{n}=15)$ according to the different EEP concentrations. Group I: $10 \%$, group II: $25 \%$, group III: 50\% EEP-Vitremer mixture, and group IV (control): $0 \%$ EEP/ Vitremer and SBS was assessed using Instron machine. B-Microhardness: Sixty standard discshaped specimens were prepared from mixture $0 \%, 10 \%, 25 \%$, and $50 \%, \mathrm{n}=15$ and nanoindentation value was recorded. Data were analyzed using one-way ANOVA and post-hoc test. Results: Only MIC of $10 \%, 25 \%$, and $50 \%$ mixture showed growth inhibition against S. mutans, compared to $25 \%$ and $50 \%$ against $\mathrm{L}$. acidophilus. SBS showed that $0 \%$ EEP recorded the highest value followed by $10 \%$ mixture but the difference was not significant ( $p>0.05$ ), while $25 \%$ and $50 \%$ reported the lowest values and the differences were significant $(\mathrm{p}<0.05) .25 \%$ and $50 \%$ mixtures recorded the highest significant microhardness $(\mathrm{p}<0.05) .0 \% \mathrm{EEP}$ and $10 \%$ mixtures displayed no significant differences between them $(\mathrm{P}>0.05)$. Conclusions: $25 \%$ EEP-Vitremer mixture was the most suitable concentration as it exhibits positive significant antibacterial and mechanical assays.
\end{abstract}

KEYWORDS: Propolis extract, fluoride-releasing restoratives, inhibition of recurrent caries, antibacterial and mechanical assays.

\section{INTRODUCTION}

One of the main contributing factors responsible for the failure of restoration is the recurrent caries. In deep caries, it is sometimes difficult to remove all carious dentin to avoid the incidence of pulp exposure. Also, the cariogenic micro-organisms can survive remaining under restorations causing recurrent caries and restoration failure ${ }^{(1-3)}$. One of the solutions to overcome this problem is the use

* Associate Professor of Pedodontics, Faculty of Dentistry, Kafrelsheikh University, Egypt.

** Associate Professor of Medical Microbiology and Immunology, Faculty of Medicine, Tanta University, Egypt. 
of restorative dental materials containing fluoride as glass-ionomer cement (GIC). It inhibits the bacterial growth and metabolism, reducing their numbers ${ }^{(4)}$, remineralizing the affected dentin and thus minimizing the risk of recurrent caries and pulp damage ${ }^{(5,6)}$.

However, Takahashi et al. ${ }^{(5)}$ showed that the amount of fluoride in GIC is insufficient for achieving the desired antimicrobial effects and did not verify whether the recurrent caries incidence can be reduced significantly ${ }^{(7)}$. Therefore, GICs may not prevent plaque proliferation and recurrent caries in some patients ${ }^{(8-10)}$, and its fluoride concentration is too low to be effective, and so it is not considered the main factor in controlling biofilm formation ${ }^{(11)}$.

Several studies ${ }^{(9,10)}$ added antibacterial agents as chlorhexidine and antibiotics to restorative materials to improve its antibacterial effects. However, it was found that the addition of chlorhexidine or its derivatives might produce pulp toxicity when applied in deep cavities and jeopardize the basic properties of the material or both ${ }^{(12,13)}$. Despite the incorporation of antibiotics into the restorative materials had a significantly strong antibacterial effect, they may produce antibiotic resistance ${ }^{(14)}$ and negatively affected the physicomechanical performance of the modified restoration ${ }^{(15,16)}$. Therefore, there is a need for alternative agents, which doesn't cause a change in physical properties of the restorative material. The particular antibacterial agent selected, its quality, quantity, and concentrations are important for incorporation into the restorative materials ${ }^{(16)}$.

Recently, a worldwide trend increased to use biocompatible natural products for pharmacological purposes. Propolis is a natural resinous bee product, so, it is an easily available and cheap. It has been used by ancient Egyptians in folk medicine as a remedy for the treatment of many diseases ${ }^{(17)}$ and in modern medicine due to a general back to nature trend. It is considered a promising agent due to its biological and pharmacological properties, such as bactericidal, antiviral, antifungal, analgesic, antioxidant, and anti-inflammatory effects ${ }^{(18,19)}$. In spite of these benefits, there are only limited reports about the addition of propolis to restorative materials as GICs.

Most of the studies ${ }^{(16,20-22)}$ have focused on the antimicrobial effects of the restorative materials, but its physicomechanical properties have been overlooked. There are two forms of propolis: ethanolic and lyophilized. Ethanolic extract of propolis (EEP) is the most commonly used one, where ethanol acts as a solvent ${ }^{(21)}$.

Most researches and cytotoxicity tests reported that propolis is safe and less toxic than other synthetic medicines ${ }^{(23-25)}$.

Currently, new techniques, approaches, and materials have focused on dentistry on the minimally invasive procedures and maximum prevention (26). According to this philosophy, resin-modified glass ionomer cement (RMGIC) is the material of choice, as it overcomes the drawback of GIC, such as poor handling characteristics, moisture sensitivity and the poor physicomechanical strength ${ }^{(14)}$. The biocompatibility and antimicrobial potential of RMGIC make the material more attractive ${ }^{(27,28)}$.

Both Streptococcus mutans and Lactobacillus acidophilus are facultatively anaerobic, grampositive bacteria found in the dental plaque and saliva of the human oral cavities. Mutans streptococci are responsible for dental caries initiation while the acidophilus lactobacilli are responsible for its progression. It is important to determine the minimal inhibitory concentration of propolis extract against both cariogenic bacteria without causing negative effects on the physicomechanical properties of incorporated RMGIC. No available data in the literature about the evaluation of antimicrobial assay against both cariogenic bacteria, and mechanical assay of EEP-RMGIC mixture. So, this study was undertaken to evaluate in-vitro the antibacterial and mechanical assays of RMGIC containing EEP. 


\section{MATERIALS AND METHODS}

\section{Preparation of Propolis Extract ${ }^{(23)}$}

Twelve and a half gm of propolis powder (Royal Pharma, USA) was dissolved in $125 \mathrm{ml}$ of ethanol $80 \%$ (vol/vol) using a magnetic stirrer for $24 \mathrm{~h}$ at room temperature. The solution was filtered, centrifuged at $8800 \mathrm{rpm}$ for $30 \mathrm{~min}$ to produce EEP, and stored at $4^{\circ} \mathrm{C}$ in dark bottle until use.

\section{Preparation of EEP added RMGIC Vitremer ${ }^{(17)}$}

Ethanolic extract of propolis was added to Vitremer Core Buildup/Restorative (3M Dental Products, St Paul, MN, USA) for further use in the antibacterial study (1gm powder=10 scoopful: 10 drops of each of 4 Vitremer liquid concentrations); EEP was added to the Vitremer liquid in 4 concentrations: $0 \%, 10 \%, 25 \%$, and $50 \%$ : (i) $0 \%$ EEP (control group): Pure Vitremer [Powder (P): Liquid (L) ratio $=1: 1$, (ii) $10 \%$ EEP-Vitremer mixture [P $\mathrm{P}^{\text {Vitremer: }} \mathrm{L}^{\text {Vitremer: }} \mathrm{L}^{\mathrm{EEP}}$ ratio=1:90:10], (iii) $25 \%$ EEP-Vitremer mixture $\left[\mathrm{P}^{\text {Vitremer: }} \mathrm{L}^{\text {Vitremer }}, \mathrm{L}^{\mathrm{EEP}}\right.$ ratio=1:0.75:0.25] and (iv) 50\% EEP-Vitremer mixture $\left[\mathrm{P}^{\text {Vitremer: }} \mathrm{L}^{\mathrm{Vitremer}}, \mathrm{L}^{\mathrm{EEP}}\right.$ ratio=1:0.5:0.5]. After mixing the powder and the liquid of Vitremer, EEP was added using a sterile micropipette.

\section{I-Antibacterial Assay}

\section{Bacterial Strains and Inoculum Preparation}

The antibacterial activity of EEP-Vitremer mixture was tested on standard strains of
Streptococcus mutans (ATCC 25175) and Lactobacillus acidophilus (ATCC 4356) [KWIKSTIK, Microbiologics, USA] (fig 1). Blood agar plates were used for inoculation of both strains and then incubated at $37^{\circ} \mathrm{C}$ for $24 \mathrm{~h}$ to get pure colonies for further manipulation.

\section{Determination of Minimum Inhibitory Concentra- tion (MIC)}

The MIC is the minimum concentration of the antimicrobial agent that inhibits the microbial growth. This parameter is used in vitro to determine the susceptibility or the resistance of microorganisms to the tested agent ${ }^{(29)}$. According to Weigand et al. ${ }^{(30)}$ broth macro dilution method was used to test the antimicrobial activity of EEP-Vitremer mixture with the different prepared concentrations.

Four sets of 9 sterile glass test tubes $10 \mathrm{ml}$ containing $1 \mathrm{ml}$ of Mueller-Hinton broth (Oxoid) were used. The previously prepared mixture with the different concentrations was added to the first tube of each set to achieve dilution of $1000 \mathrm{mg} / \mathrm{ml}$. Two serial dilutions of the mixture were performed up to the dilution of $3.9 \mathrm{mg} / \mathrm{ml}$ in the ninth tube in each set. The bacterial suspension was prepared by suspending colonies of tested control strain in a sterile saline to adjust turbidity as $0.5 \mathrm{McF}$ arland. One $\mathrm{ml}$ of the bacterial suspension was added to each test tube in the 4 sets, and then the sets were incubated at $37^{\circ} \mathrm{C}$ for $24 \mathrm{~h}$. The MIC value of the corresponding mixture was determined by the highest dilution in each set with no visible turbidity.
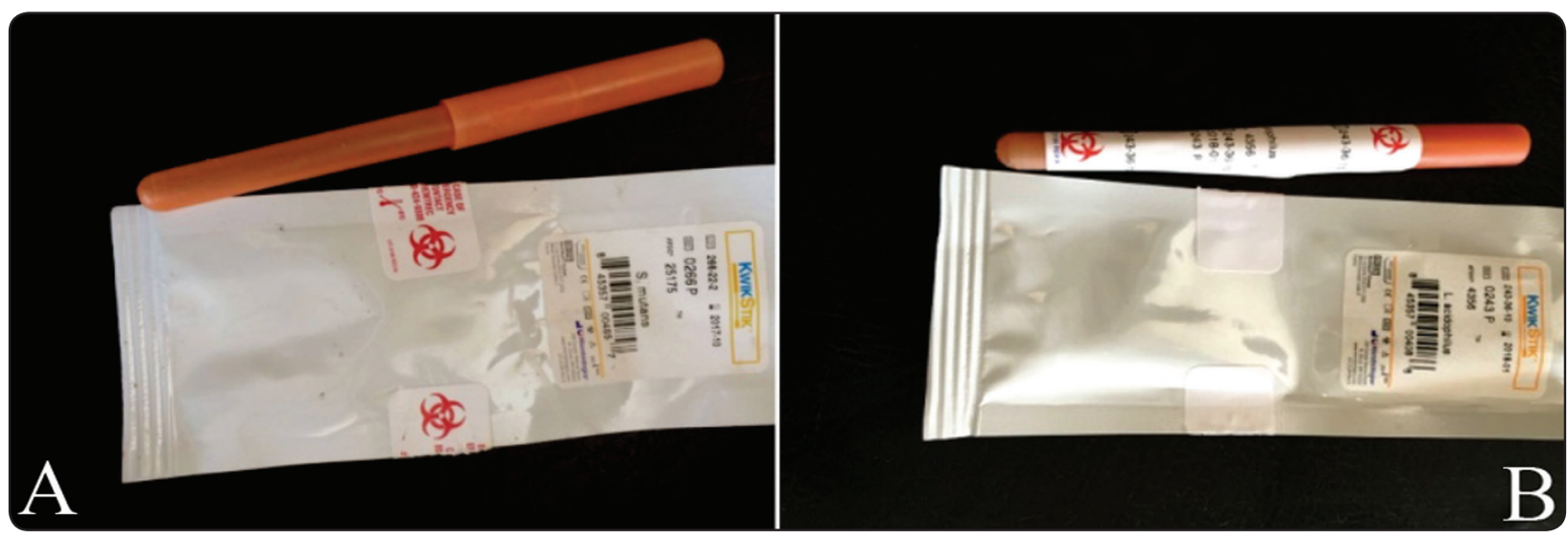

Fig. (1) Inoculating swabs of the standard strain for both $S$. mutans (A) and $L$. acidophilus (B). 


\section{II- Mechanical Assay}

\section{A. Shear bond strength testing}

Thirty crowns of non-carious extracted second primary molars due to physiologic reasons were included in this study. Immediately after the extraction, the teeth were rinsed, stored, and sterilized in $2 \%$ formaldehyde solution at $\mathrm{pH} 7.0$, at room temperature for 30 days. The teeth were cleaned, polished with slurry of pumice with a rubber cup for $15 \mathrm{sec}$, rinsed, and stored refrigerated at $4^{\circ} \mathrm{C}$ in deionized water until used ${ }^{(31)}$.

\section{Preparation of specimens}

All 30 crowns were decoronated $1 \mathrm{~mm}$ from the cemento-enamel junction and sectioned mesiodistally using a diamond disc under water cooling system to obtain 60 equal halves. Each specimen was placed at the center of a cylindrical aluminum mould using one-piece Teflon disc $3 \mathrm{~mm}$ in thickness, with a central depression that fits the bottom of the mould. The mould was filled with self-cure acrylic resin, leaving only the buccal or lingual surface of the crown protruding well above the resin.

The buccal/lingual surfaces were ground on a water-cooled trimming abrasive wheel using a sequence of fresh 120-, 220- and 400-grit silicon carbide papers to expose flat dentinal surfaces. The specimens were ground to nearly the same depth midway between the dentino-enamel junction and the pulp, followed by manual polishing with wet 600 -grit silicon carbide paper. The bonding area was demarcated with adhesive tape with a punch hole of $4 \mathrm{~mm}$ in diameter in the center of prepared dentin surface. The specimens were randomly coded and divided into four equal groups $(n=15)$, each group receiving equal numbers of buccal and lingual surfaces of primary second molars.

To build the restoration, another Teflon disc with a central hole of $4 \mathrm{~mm}$ in diameter and $3 \mathrm{~mm}$ in thickness was longitudinally split at the center. It was positioned over the specimens coinciding the central hole with the demarcated area on the prepared dentin (fig $2 \mathrm{~A}$ ). Four groups were included in this study; Group I: 10\% EPP-Vitremer mixture, Group II: 25\% EPP-Vitremer mixture, Group III: $50 \%$ EPP-Vitremer mixture and Group IV (control): $0 \%$ EPP (pure Vitremer).

\section{RMGIC build-up}

The Vitremer primer was applied to the dentinal surface for $30 \mathrm{sec}$, dried for $15 \mathrm{sec}$ and light-cured for $20 \mathrm{sec}$ using Optilux curing light (Demetron/Kerr). All shades of Vitremer were equally distributed in all groups of study. The Vitremer mixture was syringed into the central hole of a properly oriented Teflon disc and bulk-cured from the top for $60 \mathrm{sec}$. The disc was separated gently using sharp scalpel blade and light-activated again for $60 \mathrm{sec}$. The finishing gloss was applied and light-activated for $20 \mathrm{sec}$. The specimen was removed from the mould and stored in a deionized water bath for 24 hours at $37^{\circ} \mathrm{C}$ (fig 2 B \& C).

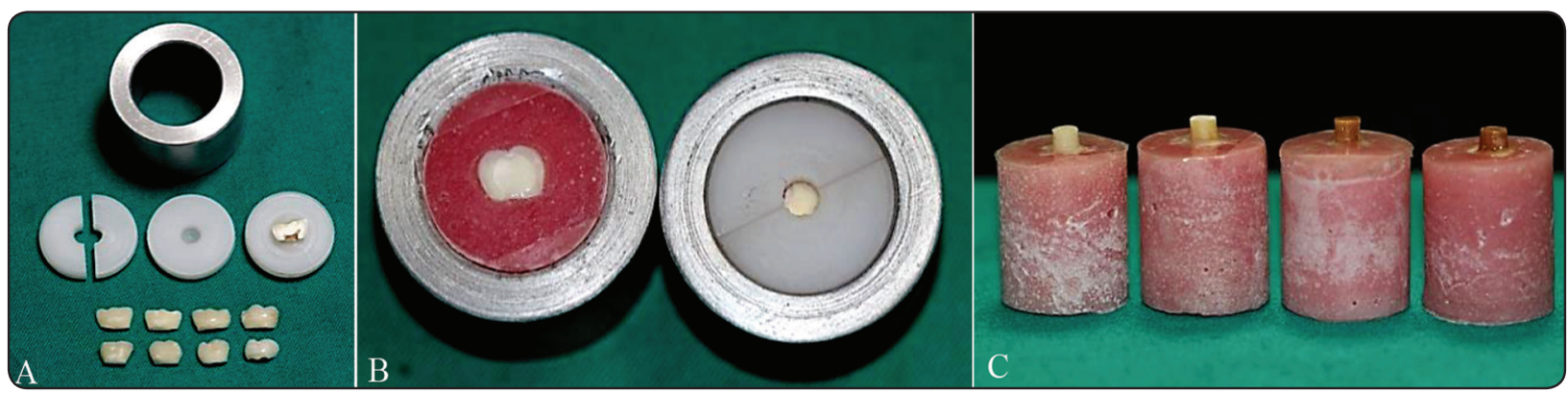

Fig. (2) Cylindrical aluminum mould, a disc longitudinally split at the central hole, Teflon disc with a circular central depression, another disc with a specimen attached to the central hole, and decoronated crown specimens of upper and lower second primary molars that were sectioned mesiodistally (A). Acrylic moulded specimen and adhesive tape with a circular hole within a metallic ring and a specimen before material application (B). Specimens representing 4 groups before SBS testing (C). 
The specimens were thermocycled in deionized water for 100 cycles between $5^{\circ} \mathrm{C}$ and $55^{\circ} \mathrm{C}$ and for $30 \mathrm{sec}$ in each dwelling temperature ${ }^{(31,32)}$. Every 100 thermocycles are equivalent to putting the specimen in the oral conditions for 10 days ${ }^{(33)}$. Any dislodged specimen was rejected and replaced.

\section{Mounting of specimens}

The shear bond strength (SBS) was assessed using an Instron machine (Bucks HP12 3SY, UK) at Dental Biomaterials Department, Faculty of Dentistry, Tanta University. A metallic tape $10 \mathrm{~cm}$ in length and $5 \mathrm{~mm}$ in width was used to apply the force at a crosshead speed of $0.5 \mathrm{~mm} / \mathrm{min}$ until failure occurred (fig 3). The SBS was measured in Mega Pascal (MPa), which is derived by dividing the maximum load force (MPa) at the time of debonding by the bonded area $\left(\mathrm{mm}^{2}\right)$.

\section{B-Microhardness}

\section{Nanoindentation testing}

Sixty standardized disc-shaped specimens $6 \mathrm{~mm}$ in diameter and $4 \mathrm{~mm}$ in thickness using Teflon moulds were prepared from EEP-Vitremer $(0 \%$,
$10 \%, 25 \%$, and $50 \%$ ) as mentioned before, 15 discs for each group. Both sides of all specimens were bulk-cured for $60 \mathrm{sec}$. To obtain a smooth and glossy surface, all specimens were ground with 400-2500 grit sandpaper and then polished by diamond pastes with mesh sizes of 1 and 0.5 microns (fig 4). All specimens were thermocycled as mentioned before, and then maintained at an ambient temperature of $24^{\circ} \mathrm{C}$ for $1 \mathrm{~h}$ before applying the test using NanoTest Vantage Micromaterials Instrument, UK, at Institute of NanoScience and Nanotechnology, Kafrelsheikh University (fig 5).

An indenter prop was pressed into specific sites of the tested specimens by applying an increasing load of $750 \mu \mathrm{N}$ with a constant rate of $15 \mu \mathrm{N} . \mathrm{s}^{-1}$. Once the pre-set maximum value was reached, the normal load was decreased until partial or complete relaxation has taken place ${ }^{(34)}$. At least each specimen was subjected to 15-cycle nanoindentations located $25 \mu \mathrm{m}$ away from each other and the mean microhardness values were recorded ${ }^{(35)}$. The results of the mechanical assay were subjected to one-way analysis of variance (ANOVA) and to Post-hoc test for pairwise comparison of subgroups when the ANOVA test is positive.

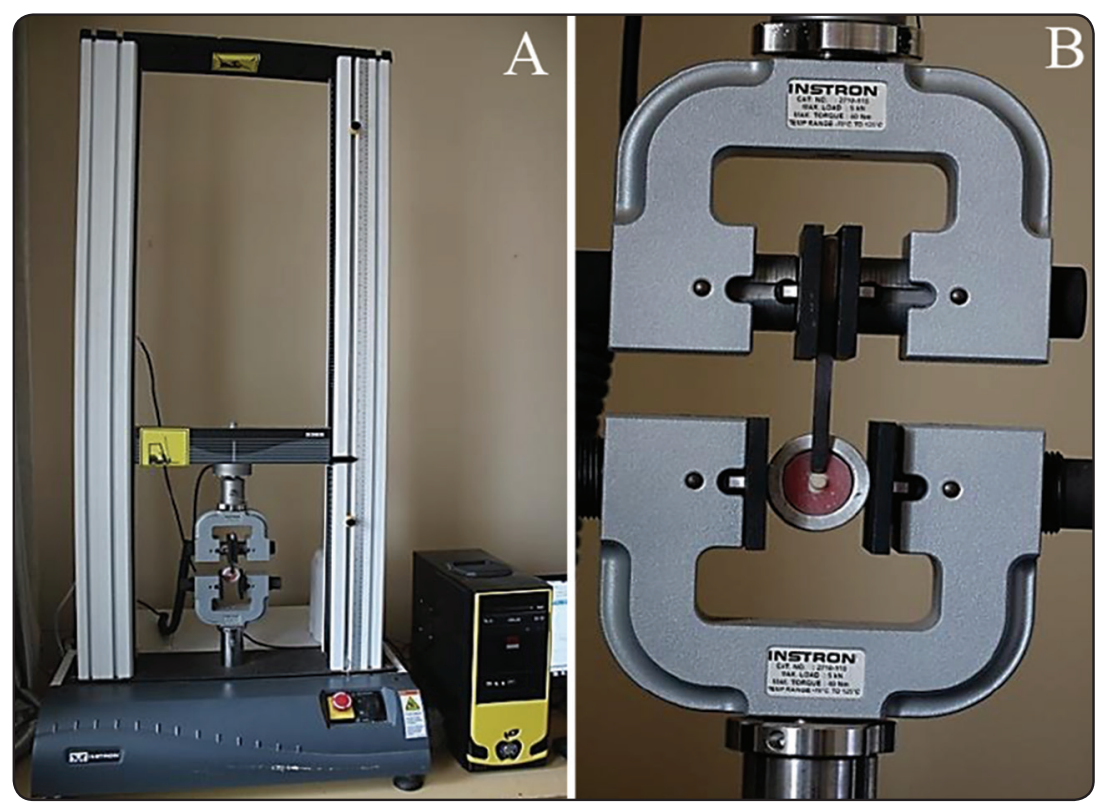

Fig. (3) Instron testing machine (A). The mounted specimen in Instron machine during SBS testing (B). 


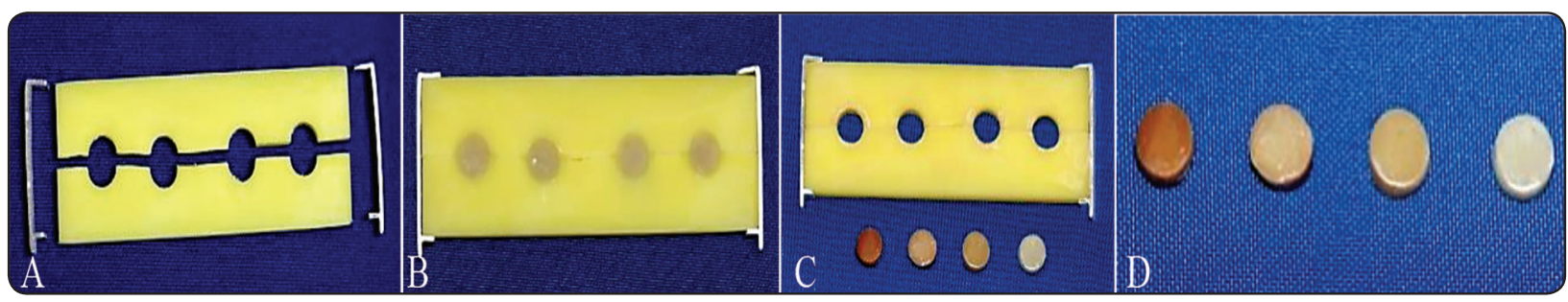

Fig. (4 Teflon mould with central holes $6 \mathrm{~mm}$ in diameter and $4 \mathrm{~mm}$ thickness (A), specimens within the mould and after light curing and removal from the mould $(B \& C)$, and the 4 discs representative specimens of the 4 groups (D).

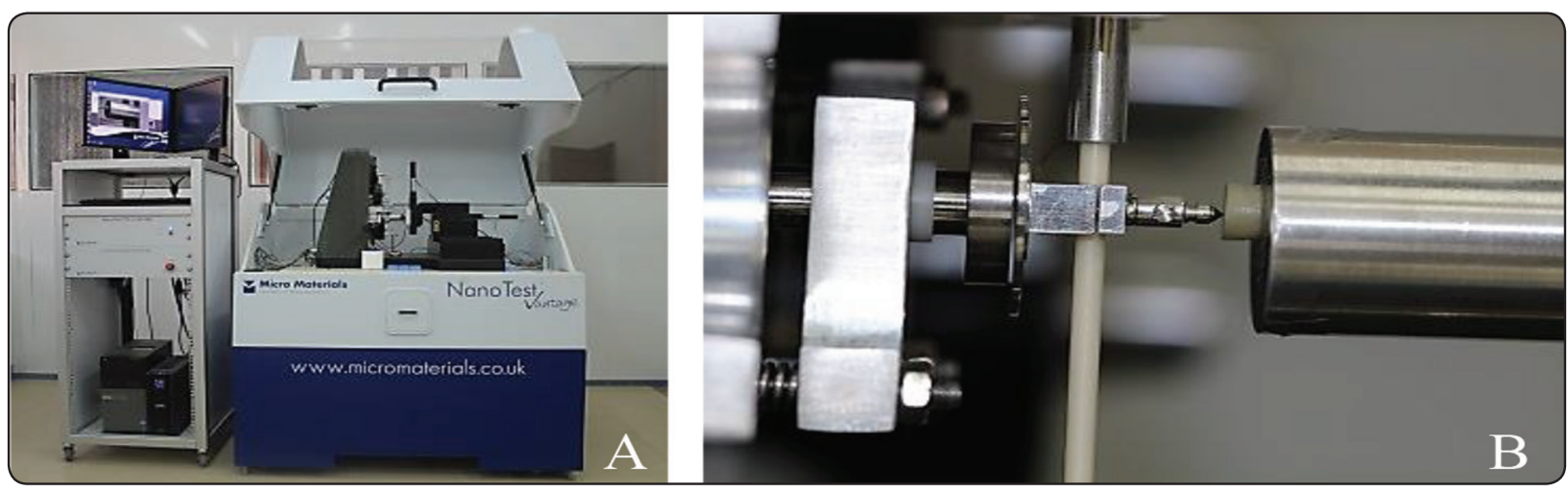

Fig. (5) NanoTest Vantage Micromaterials Instrument (A). An indenter prop is pressed into the tested specimen (B).

\section{RESULTS}

The results of broth macro dilution method used in this study showed that, the MIC values of $0 \%, 10 \%, 25 \%$ and $50 \%$ EEP-Vitremer mixture against the cariogenic bacteria were $1000 \mathrm{mg} /$ $\mathrm{ml}, 500 \mathrm{mg} / \mathrm{ml}, 125 \mathrm{mg} / \mathrm{ml}$, and $31.2 \mathrm{mg} / \mathrm{ml}$ for $S$. mutans, respectively, and $>1000 \mathrm{mg} / \mathrm{ml}, 1000 \mathrm{mg} /$ $\mathrm{ml}, 250 \mathrm{mg} / \mathrm{ml}$, and $62.5 \mathrm{mg} / \mathrm{ml}$ for $L$. acidophilus, respectively.

In particular, the MIC value of $10 \%, 25 \%$, and $50 \%$ mixture showed growth inhibition against $S$. mutans, compared to $25 \%$ and $50 \%$ mixture against L. acidophilus, MIC value of $0 \%$ EEP (control group) showed a negative effect on both cariogenic bacteria, while $10 \%$ mixture showed no efficacy for L. acidophilus.
The results of mean shear bond strength showed that $0 \%$ EEP (control group) recorded the highest values followed by $10 \%$ mixture, but there was no statistical significant difference between them ( $\mathrm{P}>0.05$ ). On the other hand, 25\% and 50\% mixtures recorded the lowest values and the difference was significant $(\mathrm{P}<0.05)$. Table1.

The results of microhardness values obtained from the nanoindentation experiment of the specimens showed that $25 \%$ and $50 \%$ mixtures recorded the highest significant differences than $0 \%$ EEP and $10 \%$ mixtures $(\mathrm{p}<0.05) .0 \%$ EEP and $10 \%$ mixtures displayed no statistically significant differences between them $(\mathrm{P}>0.05)$. Table 2 and figure 6 . 
TABLE (1) The shear bond strength between experimental and control group (MPa).

\begin{tabular}{|c|c|c|c|c|c|c|c|}
\hline & \multirow{2}{*}{ Groups } & \multirow{2}{*}{$\begin{array}{c}\text { Specimens } \\
\text { No. }\end{array}$} & \multicolumn{3}{|c|}{ Shear bond strength } & \multirow{2}{*}{$\begin{array}{c}\text { F-Test } \\
\text { (p-value) }\end{array}$} & \multirow{2}{*}{$\begin{array}{l}\text { Post Hoc Test } \\
(\mathbf{P}<0.05)\end{array}$} \\
\hline & & & Mean \pm SD & Minimum & Maximum & & \\
\hline $\mathbf{I}$ & $10 \%$ Mixture & \multirow{4}{*}{15} & $7.82 \pm 0.30$ & 7.10 & 8.6 & \multirow{4}{*}{$\begin{array}{c}305.386 \\
(0.001)^{* *}\end{array}$} & $\begin{array}{l}P_{1} \\
\mathbf{p}_{* * *}\end{array}$ \\
\hline II & 25\% Mixture & & $6.87 \pm 0.42$ & 6.20 & 7.60 & & $P_{3}$ \\
\hline III & $50 \%$ Mixture & & $3.85 \pm 0.52$ & 3.00 & 4.47 & & $\mathbf{P} 4^{* *}$ \\
\hline IV & 0\% Control & & $8.25 \pm 0.49$ & 7.50 & 9.10 & & $P 6^{* * *}$ \\
\hline
\end{tabular}

\#ANOVA Test *Significant difference **Highly significant difference

1-P $P_{1}$ : Comparison between $10 \%$ and $25 \%$ mixture. 2-P: Comparison between 10\% and 50\% mixture. 3-P3: Comparison between 10\% mixture and control. 4-P4: Comparison between 25\% and 50\% mixture. 5- P5: Comparison between 25\% mixture and control. 6-P6: Comparison between 50\% mixture and control.

TABLE (2) Microhardness between experimental and control group (GPa) using Nano-scale measurement.

\begin{tabular}{|c|c|c|c|c|c|c|c|}
\hline & \multirow{2}{*}{ Groups } & \multirow{2}{*}{$\begin{array}{c}\text { Specimens } \\
\text { No. }\end{array}$} & \multicolumn{3}{|c|}{ Nano indentation micro hardness } & \multirow{2}{*}{$\begin{array}{c}\text { F-Test } \\
\text { (p-value) }\end{array}$} & \multirow{2}{*}{$\begin{array}{c}\text { Post Hoc Test } \\
(\mathbf{P}<\mathbf{0 . 0 5})\end{array}$} \\
\hline & & & Mean \pm SD & Minimum & Maximum & & \\
\hline I & $10 \%$ Mixture & \multirow{5}{*}{15} & $6.79 \pm 0.58$ & 5.60 & 7.90 & \multirow{5}{*}{$\begin{array}{c}300.338 \\
(0.001)^{* *}\end{array}$} & $\mathbf{P}_{1}^{* *}$ \\
\hline II & $25 \%$ Mixture & & $11.51 \pm 0.44$ & 10.80 & 12.20 & & $\mathbf{P}_{2}$ \\
\hline III & $50 \%$ Mixture & & $17.00 \pm 0.93$ & 16.000 & 19.90 & & $\mathbf{P} \mathbf{4}^{* *}$ \\
\hline IV & $0 \%$ Control & & $5.41 \pm 0.53$ & 4.26 & 6.30 & & $\mathbf{P 5}^{* *}$ \\
\hline & - & & & & & & P6 ${ }^{* *}$ \\
\hline
\end{tabular}

\#ANOVA Test *Significant difference **Highly significant difference

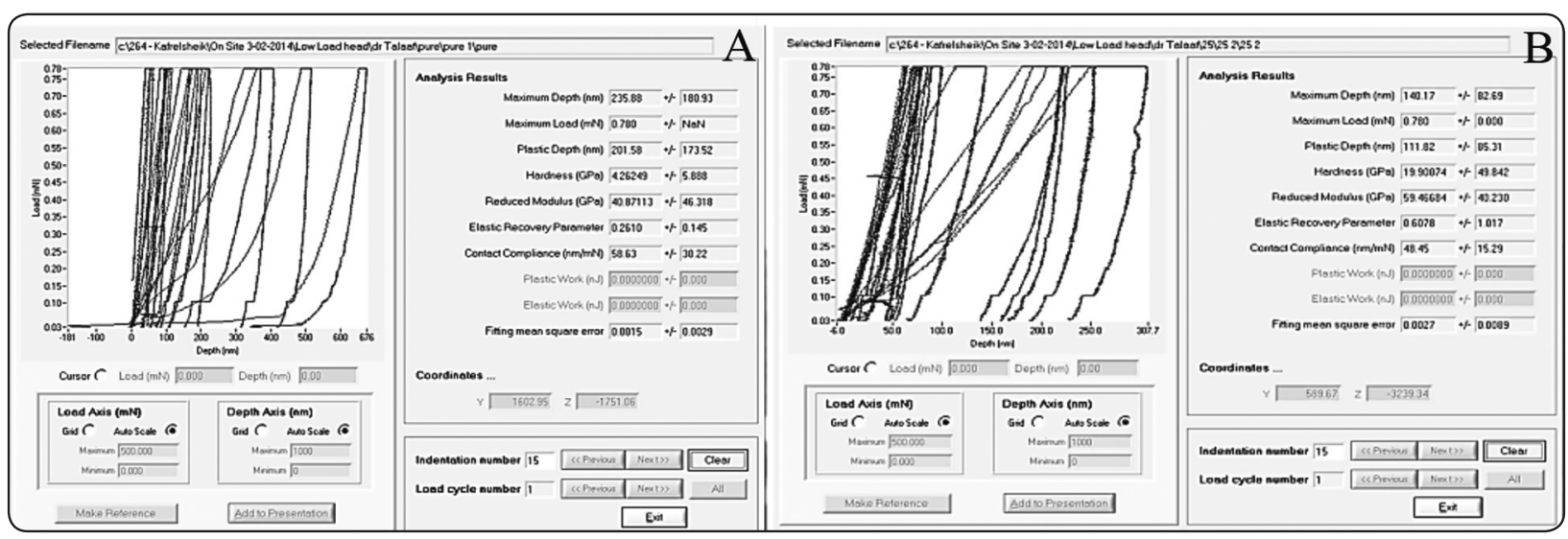

Fig. (6) Nano-scale measurement analysis illustrated with graphs showed the minimum value (A) and the maximum value (B). 


\section{DISCUSSION}

Recently, utilization of antibacterial agents in restorative materials is recommended to aid in the prevention of recurrent caries ${ }^{(6)}$, With the advanced technology in dentistry, new materials and approaches were developed ${ }^{36,37)}$; propolis seems to be a great choice for dental treatment. It has been the topic of increasing the scientific interest and has the potential of use in the treatment of bacterial disease ${ }^{(38,39)}$. This encourages its addition in this study to the favorite modified GICs system in pedodontics restorative materials.

Resin-modified GICs have been developed by addition of $4.5 \%-6 \%$ resin-based composites to conventional GIC to overcome the drawback of physicomechanical properties of GICs, but maintaining their fluoride release and "recharging," and chemical adhesiveness to the tooth structure(40,41). The significant anti-cariogenicity of GIC through long-term fluoride release makes the material more popular and widely used, especially in pedodontics. Therefore, the antibacterial modified RMGICs would provide an alternative approach to overcome this concept ${ }^{(26,42)}$ and make it the material of choice to high caries-risk patients ${ }^{(43)}$.

In this study, the ethanolic extract was used rather than lyophilized one as it was found that incorporation of lyophilized propolis leads to a hard and difficult manipulation with the color change of any GIC systems ${ }^{(14)}$. Additionally, there is a lack of reports on the use of the lyophilized form ${ }^{(44)}$. Often, EEP is directly used, resulting in effective antimicrobial potential ${ }^{(16,20)}$.

This study focused on both antibacterial and mechanical assays of EEP-Vitremer mixture. Both $S$. mutans and $L$. acidophilus were used to determine antibacterial activity, as they are considered the main contributor to dental caries ${ }^{(23,45)}$.

In this study, the buccal/lingual surfaces of specimens protruded above the resin mould to avoid any possible surface contamination by resin when the surfaces were ground flat. Also, the surfaces were ground to approximately the same depth midway between the dento-enamel junction and the pulp to represent a site nearly similar to the depth of a typical cavity preparation for testing the shear bond strength ${ }^{(46)}$. In the current study, to mimic the intra-oral environmental condition, all specimens were thermocycled 100 times; as it was reported that the thermocycling more than 100 cycles have been shown to be unnecessary ${ }^{(47)}$.

Because the resin shades can influence the hardness ${ }^{(48)}$ and bond strength ${ }^{(49)}$, all shades of the Vitremer powder in this study were equally distributed in all groups. The lighter the shade, is the greater the hardness and bond strength ${ }^{(50)}$.

In this study, the addition of EEP to Vitremer may show alterations, so, the antibacterial and mechanical assays were important to be investigated. The MIC, SBS, and Nanoindentation testing were applied.

The antimicrobial assay in this study reported that EEP has a positive impact on the antibacterial properties of Vitremer. The MIC value of $10 \%$, $25 \%$, and $50 \%$ mixture was $500 \mathrm{mg} / \mathrm{ml}, 125 \mathrm{mg} /$ $\mathrm{ml}$, and $31.2 \mathrm{mg} / \mathrm{ml}$ respectively, showed growth inhibition against $S$. mutans, compared to $25 \%$ and $50 \%$ mixture against L. acidophilus which was $250 \mathrm{mg} / \mathrm{ml}$, and $62.5 \mathrm{mg} / \mathrm{ml}$, respectively. Thus these only the MIC values of the mixture that have a significant activity against both cariogenic bacterial growth.

The results of MIC for $S$ mutans are comparable to the findings of Hatunoğlu et al. ${ }^{(23)}$, who found that MIC of both $0 \%$ and $10 \% \mathrm{EEP}>1000 \mu \mathrm{g} / \mathrm{ml}$, while $25 \%$ and $50 \%$ recorded $125 \mathrm{mg} / \mathrm{ml}$ and $31.2 \mathrm{mg} /$ $\mathrm{ml}$, respectively. Kouidhi et al. ${ }^{(51)}$ reported $8-32 \mu \mathrm{g} /$ $\mathrm{ml}$, while Koo et al. ${ }^{(52)}$ recorded $50-400 \mu \mathrm{g} / \mathrm{ml}$. The change in MIC values may be due to differences in the botanical origin, geographical location and bee species, leading to change in chemical composition of propolis, and leading to a significant change of antibacterial activity of all specimens (53,54). 
Also, this result is in agreement with the studies of Türkün et al. ${ }^{(13)}$ and Deepalakshmi et al. ${ }^{(42)}$ who reported that the antimicrobial efficacy was depended on the concentration of antibacterial added to restorative materials, but Jedrychowski et al. ${ }^{(55)}$ showed no dose-response effects.

The mechanism of antibacterial effects of propolis is very complex. Some components such as high flavonoids concentration, caffeic $^{(56)}$, benzoic and cinnamic acids probably act on the bacterial cell wall or the cytoplasmic membrane, causing structural and functional damages ${ }^{(57)}$. Also, the antimicrobial effect may be due to the synergistic action of all components rather than an individual one $\mathrm{s}^{(58)}$ and/or inhibition of glucosyltransferase enzymes activity ${ }^{(38,39)}$.

The increases of the antibacterial activity of the mixture in this study coincide with the study of Stuart ${ }^{(59)}$ who reported that EEP added to GICs system has a greater positive antimicrobial effect, especially against $S$. mutans, most of the Strept. Species and L. acidophilus ${ }^{(60)}$. Waldner et al. ${ }^{(61)}$ found that propolis may require high concentrations to develop into an antiseptic agent.

Also, the results of this study are in agreement with the in vitro study conducted by Herrera et al. ${ }^{(62)}$ who revealed that Vitremer was the best material that showed bacterial inhibition against Streptococcus spp, Lactobacillus spp, and other bacterial species among the other glass ionomer filling materials as Ketac-Silver, Ketac-Fil, and Fuji II LC.

The variation in the antibacterial effects of GIC system might be due to their difference in compositions, such as presence or absence of oxides, type of acids, and fluoride release ${ }^{(63)}$. Therefore, in this study explaining the significant positive antibacterial activity of mixture may be related to the presence of polyacid, the antibacterial activity of EEP, and the high fluoride release that may results from addition of EEP ${ }^{(64)}$, and the slowdown of acid-based reactions by the resin would lead to less mature ionic matrix and release of more fluoride ${ }^{(65,66)}$.
The mean shear bond strength of $0 \%$ EEP, $10 \%$, $25 \%$ and $50 \%$ mixture in this study was $8.25,7.82$, 6.87 , and $3.85 \mathrm{MPa}$, respectively. This agrees with the study of Carrara et al. ${ }^{(67)}$ and Di Nicoló et al. ${ }^{(68)}$ who found that the shear bond strength of $0 \%$ EEP recorded 9.02 and $8.33 \mathrm{MPa}$, respectively; however, El-Kalla and Garcia-Godoy ${ }^{(69)}$ reported 16.9 MPa.

This study revealed that the mixture had no significant deleterious effect on SBS at $10 \%$ and $25 \%$ mixture. This is in agreement with Troca et al. ${ }^{(14)}$ who found that adding EEP has a negative effect on GIC system but disagree with the result of Hatunoğlu et al. ${ }^{(23)}$ who reported that the increase of shear-peel band strength with the addition of EEP, but statistically the difference was not significant.

The significant inferior bond strength value of $50 \%$ mixture recorded $3.85 \mathrm{MPa}$ may be attributed to the change in physical properties. The viscosity of Vitremer liquid decreases by adding EEP that prolongs the working time ${ }^{(23)}$ and interferes with the network formation of GIC systems. The high percent of EEP would weaken the scaffold with unfavorable adhesion leading to a negative effect on the physical properties of the mixture ${ }^{(17)}$.

Despite adding the antibacterial to GIC system enhanced its antimicrobial activity; Yesilyurt et al. ${ }^{(16)}$ showed that the bond and compressive strengths of GIC system were negatively affected. However, de-Castilho et al. ${ }^{(70)}$ stated that the negative results of compressive strength were not statistically significant.

Surface microhardness is one of the most important tests giving information about wear resistance and long-term durability of materials when exposed to the intra-oral environmental condition $^{(71,72)}$. Nano-indentation measurement is a proper test for recording the mechanical properties of small-sized specimens and the surface properties of coatings.

In the present study, the microhardness of $25 \%$ and $50 \%$ mixture recorded the highest values than 
$10 \%$ mixture and control group and the difference was significant. A possible explanation for this finding is that EEP molecule contained highly active polyphenolic compounds and many aromatic fatty acids that have numerous favorable properties ${ }^{(73,74)}$; a chelation reaction was formed between the carboxylic group of Vitremer and phenolic hydroxyl of EEP ${ }^{(75)}$. The EEP act as a spacer for the dissociative carboxyl, provide highly active poly-salt bridging and increasing of cross-links. Following the addition of EEP, a greater amount of poly-salt bridges was formed that minimize the gaps existing among the crosslink networks with the increase of the molecules intensity on the surface $^{(76-78)}$.

One of the limitations of this study is that the mixture required accuracy of preparation to obtain adequate consistency without compromising the properties of the material. Another limitation is the color change of the mixture with the addition of a high EEP concentration that may compromise the restorative color match ${ }^{(14)}$.

\section{CONCLUSION}

Based on the results of this in vitro study, despite some limitations; EEP-Vitremer mixture is promising; its incorporation into Vitremer in addition to the fluoride release will have a clinical interest due to their synergetic antibacterial action, significantly increase the microhardness, and had no significant deleterious effect on SBS except with $25 \%$ and $50 \%$ EEP concentration.

\section{REFERENCES}

1. Weerheijm LK, Kreulen CM, de Soet JJ, Groen HJ, van Amerongen WE. Bacterial counts in carious dentine under restorations: 2-year in vivo effects. Caries Res 1999; 33:130-134.

2. Hicks J, Garcia-Godoy F, Donly K, Flaitz C. Fluoridereleasing restorative materials and secondary caries. J Calif Dent Assoc 2003; 31:229-245.

3. Van Amerongen WE. Dental caries under glass ionomer restorations. J Public Health Den 1996; 56:150-154.
4. Pinheiro SL, Simionato MR, Imparato JC, Oda M. Antibacterial activity of glass-ionomer cement containing antibiotics on caries lesion microorganisms. Am J Dent 2005; 18:261-266.

5. Takahashi Y, Imazato S, Kaneshiro AV, Ebisu S, Frencken JE, Tay FR. Antibacterial effects and physical properties of glass-ionomer cements containing chlorhexidine for the ART approach. Dent Mater 2006; 22: 647-652.

6. Dionysopoulos D. The effect of fluoride-releasing restorative materials on inhibition of secondary caries formation. Res Rev F 2014; 47:258-265.

7. Cabral MC, Martinho RM, GuedesNeto MV, Rebelo MB, Pontes DG, Cohen-Carneiro F. Do conventional glass ionomer cements release more fluoride than resinmodified glass ionomer cements? Restor Dent Endod 2015; 40: 209-215.

8. Al-Naimi OT, Itota T, Hobson RS, McCabe FJ. Fluoride Release for Restorative Materials and Its Effect on Biofilm Formation in Natural Saliva. J Mater Sci Mater Med 2008; 19:1243-1248.

9. Hoszek A, Ericson D. In vitro fluoride release and the antibacterial effect of glass ionomers containing chlorhexidine gluconate. Oper Dent 2008; 33:696-701

10. Farret MM, de Lima EM, Mota EG, Oshima HM, Barth $\mathrm{V}$, de Oliveira SD. Can we add chlorhexidine into glass ionomer cements for band cementation? Angle Orthod 2011; 81: 496-502.

11. Wiegand A, Buchalla W, Attin T. Review on FluorideReleasing Restorative Materials-Fluoride Release and Uptake Characteristics, Antibacterial Activity and Influence on Caries Formation. Dent Mater 2007; 23: 343-362.

12. Duque C, Negrini TC, Hebling J, Spolidorio DP. Inhibitory activity of glass-ionomer cements on cariogenic bacteria. Oper Dent 2005; 30:636-640.

13. Türkün LS, Türkün M, Ertug rul F, Ates M, Brugger S. Long term antibacterial effects and physical properties of a chlorhexidine-containing glass ionomer cement. J Esthet Restor Dent 2008; 20:29-44.

14. Troca VB, Fernandes KP, Terrile AE, Marcucci MC, de Andrade FB, Wang L. Effect of green propolis addition to physical mechanical properties of glass ionomer cements. J Appl Oral Sci 2011; 19:100-105.

15. Mittal S, Soni H, Sharma DK, Mittal K, Pathania V, Sharma S. Comparative evaluation of the antibacterial and physical properties of conventional glass ionomer cement containing chlorhexidine and antibiotics. J Int Soc Prev Community Dent 2015; 5:268-275. 
16. Yesilyurt C, Er K, Tasdemir T, Buruk K, Celik D. Antibacterial activity and physical properties of glassionomer cements containing antibiotics. Oper Dent 2009; $34: 18-23$.

17. Topcuoglu N, Ozan F, Ozyurt M, Kulekci G. In vitro antibacterial effects of glass-ionomer cement containing ethanolic extract of propolis on Streptococcus mutans. Eur J Dent 2012; 6:428-433.

18. Paulino N, Teixeira C, Martins R, Scremin A, Dirsch VM, Vollmar AM, et al. Evaluation of the analgesic and antiinflammatory effects of a Brazilian green propolis. Planta Med 2006; 72:899-906.

19. Kujumgiev A, Tsvetkova I, Serkedjieva Y, Bankova V, Christov R, Popov S. Antibacterial, antifungal and antiviral activity of propolis of different geographic origin. J Ethnopharmacol 1999; 64:235-240.

20. Rezende GR, Pimenta FC, Costa LS. Antimicrobial activity of two Brazilian commercial propolis extracts. Braz J Oral Sci 2006; 5:967-70.

21. Ferreira HC, Rego MA. Evaluation in vitro of properties physicist chemistries of glass-ionomer cements, after addition of propolis and antibiotics. Ciênc Odontol Bras 2006; 9:38-46

22. Peez R, Frank S. The physical-mechanical performance of the new Ketac Molar Easymix compared to commercially available glass ionomer restoratives. J Dent 2006; 34:582-587.

23. Hatunoğlu E, Oztürk F, Bilenler T, Aksakallı S, Simşek N. Antibacterial and mechanical properties of propolis added to glass ionomer cement. Angle Orthod 2014; 84:368-73

24. Moreno MN, Zampini IC, Ordonez RM, Jaime GS, Vattuone MA, Isla MI. Evaluation of the cytotoxicity, genotoxicity, mutagenicity, and antimutagenicity of propolis from Tucuman, Argentina. J Agric Food Chem 2005; 53:8957-8962.

25. Sonmez S, Kirilmaz L, Yucesoy M, Yucel B, Yilmaz B. The effect of bee propolis on oral pathogens and human gingival fibroblasts. J Ethnopharmacol 2005; 102:371-376.

26. Ellakuriaa J, Trianaa R, Míngueza N, Solerb I, Ibasetaa G, Mazab J, García-Godoyc F. Effect of one-year water storage on the surface microhardness of resin-modified versus conventional glass-ionomer cements. Dent Mater 2003; 19: 286-290.

27. Can-Karabuut DC, Batmaz I, Solak H, Taştekin M. Linear regression modeling to compare fluoride release profiles of various restorative materials. Dent Mater 2007; 23:1057-1065.
28. Sidhu SK. Clinical evaluations of resin-modified glassionomer restorations. Dent Mater 2010; 26: 7-12.

29. Andrews JM. Determination of minimum inhibitory concentrations. J Antimicrob Chemother 2001; 48:5-16.

30. Wiegand I, Hilpert K and Hancock REW. Agar and broth dilution methods to determine the minimal inhibitory concentration (MIC) of antimicrobial substances. Nat Prot 2008; 3: 163-175.

31. Fitchie JG, Puckett AD, Reeves GW, Hembree JH. Microleakage of a new dental adhesive comparing microfilled and hybrid resin composites. Quintessence Int 1995; 26:505-510.

32. Gale M, Darvell B. Thermal cycling procedures for laboratory testing of dental restorations. J Dent 1999; 27: 89-99.

33. Brown WS, Jacobs HR, Thompson RE. Thermal fatigue in teeth. J Dent Res 1972; 51: 461-467.

34. Karimzadeh A, Ayatollahi MR, Shirazi HA. Mechanical Properties of a Dental Nano-Composite in Moist Media Determined by Nano-Scale Measurement. IJMMM 2014; 2: $67-72$.

35. Karimzadeh A, Ayatollahi MR, Hosseinzadeh-Nik T, Effects of a Nano-composite Adhesive on Mechanical Properties of Tooth Enamel After Removing Orthodontics Bracket - an Experimental Study Using Nano-indentation Test. Exp Mech 2015;55:1769-1777.

36. Bertolini MJ, Zaghete MA, Gimenes R, Padovani GC. Determination of the properties of an experimental glass polyalkenoate cement prepared from niobium silicate powder containing fluoride. Dent Mater 2008; 24:124-128.

37. Hiraishi N, Yiu CK, King NM, Tay FR, Pashley DH. Chlorhexidine release and water sorption characteristics of chlorhexidine incorporated hydrophobic/hydrophilic resins. Dent Mater 2008; 24:1391-1399.

38. Libério SA, Pereira AL, Araújo MJ, Dutra RP, Nascimento FR, Monteiro-Neto V, et al. The potential use of propolis as a cariostatic agent and its actions on mutans group streptococci. J Ethnopharmacol 2009; 125:1-9.

39. Hayacibara MF, Koo H, Rosalen PL, Duarte S, Franco $\mathrm{EM}$, Bowen $\mathrm{WH}$, et al. In vitro and in vivo effects of isolated fractions of Brazilian propolis on caries development. J Ethnopharmacol 2005; 101:110-115.

40. Sidhu SK1, Watson TF. Resin-modified glass ionomer materials. A status report for the American Journal of Dentistry. Am J Dent 1995; 8:59-67.

41. Cortés O, García C, Pérez L, Bravo LA. A comparison of the bond strength to enamel and dentin of two compomers: an in vitro study. ASDC J Dent Child 1998;65:29-31. 
42. Deepalakshmi M, Poorni S, Miglani R, Rajamani I, Ramachandran S. Evaluation of the antibacterial and physical properties of glass ionomer cements containing chlorhexidine and cetrimide: an in-vitro study. Indian J Dent Res 2010; 21:552-556.

43. Wang L, Lopes LG, Bresciani E, Lauris JP, Mondelli RL, Navarro ML. Evaluation of Class I ART restorations in Brazilian schoolchildren: three-year results. Spec Care Dentist 2004; 24:28-33.

44. Sosnowski, Zenon M. Method for extracting propolis and water soluble dry propolis powder. US 4382886 A. 1983 Oct. 05 .

45. Duailibe SA, Goncalves AG, Ahid FJ. Effect of a propolis extract on Streptococcus mutans counts in vivo. J Appl Oral Sci 2007; 15:420-423

46. Price RB, Doyle G, Murphy D. Effects of composite thickness on the shear bond strength to dentin. J Can Dent Assoc 2000; 66:35-39.

47. Burger KM, Cooly RL, Garcia-goody F. Effect of Thermocycling Times on Dentin Bond Strength bond. J Esthet Dent 1992; 4:197-198

48. Caughman WF, Rueggeberg FA, Curtis JW, Jr. Clinical guidelines for photocuring restorative resins. J Am Dent Assoc 1995; 126:1280-1282.

49. Miyazaki M1, Hinoura K, Onose H, Moore BK. Influence of light intensity on shear bond strength to dentin. Am J Dent 1995;8:245-8.

50. Friedman J, Hassan R. Comparison study of visible curing lights and hardness of light-cured restorative materials. J Prothet Dent 1984; 52:504-506.

51. Kouidhi B, Zmantar T, Bakhrouf A. Anti-cariogenic and anti-biofilms activity of Tunisian propolis extract and its potential protective effect against cancer cells proliferation. Anaerobe 2010; 16:566-571.

52. Koo H, Rosalen PL, Cury JA, Ambrosano GM, Murata RM, Yatsuda R, et al. Effect of a new variety of Apis mellifera propolis on mutans streptococci. Curr Microbiol 2000; 41:192-196.

53. Huang S, Zhang CP, Wang K, Li GQ, Hu FL. Recent advances in the chemical composition of propolis. Molecules 2014;19:19610-19632.

54. Kujumgiev A, Tsvetkova I, Serkedjieva Y, Bankova V, Christov R, Popov S. Antibacterial, antifungal and antiviral activity of propolis of different geographic origin. J Ethnopharmacol 1999; 64:235-240.

55. Jedrychowski JR, Caputo AA, Kerper S. Antibacterial and mechanical properties of restorative materials combined with chlorhexidines. J Oral Rehabil 1983; 10:373-381.
56. Liberio SA, Pereira AL, Dutra RP, Reis AS, Araújo MJ, Mattar NS, et al. Antimicrobial activity against oral pathogens and immunomodulatory effects and toxicity of geopropolis produced by the stingless bee Melipona fasciculata Smith. BMC Complement Altern Med 2011;11:108

57. Akca AE, Akca G, Topçu FT, Macit E, Pikdöken L, Özgen I. The comparative evaluation of the antimicrobial effect of propolis with chlorhexidine against oral pathogens: An in vitro study. Biomed Res Int 2016; 2016, Article ID 3627463,8 pages.

58. Amoros M, Lurton E, Boustie J, Girre L, Sauvager F, Cormier M. Comparison of the anti-herpes simplex virus activities of propolis and 3-methyl-but-2-enyl caffeate. J Nat Prod 1994; 57:644-647.

59. Stuart T. Effect of Propolis-Based Antimicrobial on Oral Bacteria Conference: AADR Annual Meeting 2012

60. Haddadinv MY, Nazer I, Abu Raddad SJ, Robinson RK. Effect of Propolis on Two Bacterial Species with Probiotic Potential. Pakistan J Nutr 2008; 7: 391-394.

61. Waldner-Tomic NM, Vanni R, Belibasakis GN, Thurnheer T, Attin T, Schmidlin, PR. The in Vitro Antimicrobial Efficacy of Propolis against Four Oral Pathogens. A Review. Dent J 2014; 2: 85-97.

62. Herrera M, Castillo A, Bravo M, Liebana J, Carrion P. Antibacterial activity of resin adhesives, glass ionomer and resin-modified glass ionomer cements and a compomer in contact with dentin caries samples. Oper Dent 2000; $25: 265-269$.

63. Ferreira GS, Freires IA, Alves LA, Jovito VC, de Carvalho FG, de Castro RD. Antibacterial Activity of Glass Ionomer Cements on Cariogenic Bacteria-An in vitro study. Int J Dent Clin 2011; 3:1-3.

64. Prabhakar AR, Balehosur DV, Basappa N. Comparative Evaluation of Shear Bond Strength and Fluoride Release of Conventional Glass Ionomer with 1\% Ethanolic Extract of Propolis Incorporated Glass Ionomer Cement -Invitro Study. J Clin Diagn Res 2016; 10: ZC88-ZC91.

65. Dionysopoulos P, Kotsanos N, Pataridou A. Fluoride release and uptake by four new fluoride releasing materials . J Oral Rehabil 2003; 30:866-872.

66. Hsu HM, Huang GF, Chang HH, Wang YL, Guo MK. A continuous flow system for assessing fluoride release/ uptake of fluoride-containing restorative materials. Dent Mater 2004; 20:740-749. 
67. Carrara C E, Abdo RC, da Silva SB, ,Carrara CF. Shear bond strength of restorative materials to deciduous teeth. Salusvita Bauru 2001; 20: 71-79,

68. Di Nicoló R, Shintome LK, Myaki SI, Nagayassu MP. Bond strength of resin modified glass ionomer cement to primary dentin after cutting with different bur types and dentin conditioning. J Appl Oral Sci 2007;15:459-464.

69. El-Kalla I H, Garcia-Godoy F. Bond strength and interfacial micromorphology of compomers in primary and permanent teeth. Int J Paediatr Dent 1998; 8: 103- 114.

70. de Castilho AR, Duque C, Negrini TC, Sacono NT, de Paula AB, Sacramento PA, et al. Mechanical and biological characterization of resin-modified glass-ionomer cement containing doxycycline hyclate. Arch Oral Biol 2012; 57:131-138.

71. Shiozawa M, Takahashi H, Iwasaki N, Uo M. Effect of calcium chloride solution immersion on surface hardness of restorative glass ionomer cements. Dent Mater J 2013; 32: $828-833$.

72. Nicholson JW. Chemistry of glass-ionomer cements: a review. Biomaterials 1998; 19: 485-494.
73. Vinson JA, Su X, Zubik L, Bose P. Phenol antioxidant quantity and quality in foods: fruits. J Agric Food Chem 2001; 49: 5315-5321.

74. Tipoe GL, Leung TM, Hung MW, Fung ML. Green tea polyphenols as an anti-oxidant and anti-inflammatory agent for cardiovascular protection. Cardiovasc Hematol Disord Drug Targets 2007; 7: 135-144.

75. Lo CY, Hsiao WT, Chen XY. Efficiency of trapping methylglyoxal by phenols and phenolic acids. J Food Sci 2011; 76: 90-96.

76. Hu J, Du X, Huang C, Fu D, Ouyang X, Wang Y. Antibacterial and physical properties of EGCG-containing glass ionomer cements. J Dent 2013; 41: 927-934.

77. Prentice LH, Tyas MJ, Burrow MF. The effect of ytterbium fluoride and barium sulphate nanoparticles on the reactivity and strength of a glass-ionomer cement. Dent Mater 2006; 22: 746-751.

78. Zanata RL, Magalhaes AC, Lauris JR, Atta MT, Wang L, Navarro MF. Microhardness and chemical analysis of highviscous glass-ionomer cement after 10 years of clinical service as ART restorations. J Dent 2011; 39: 834-840. 